\title{
Market Potential Exploration of Tourism Sector and Local Tourists' Perception
}

\author{
Nanang Wahyudin ${ }^{\text {* }}$, Sandy Pratama ${ }^{\mathrm{b}}$, Muhammad Faisal Akbar \\ ${ }^{a, b, c}$ Universitas Bangka Belitung, Indonesia \\ nanang.w19@gmail.com
}

\begin{abstract}
This research discussed domestic tourists' perception of tourism destination in Pangkalpinang, Indonesia. It has been formed a perception index using PCA with determined indicators such as accessibility, supporting facilities, the prices of snacks and security. The result indicates that most of the visitors have good perceptions of tourism destinations in Pangkalpinang. Nevertheless, there is an aspect that should be evaluated; it is about the availability of toilets at those tourist destinations. There is 53 percent of domestic tourists tell that there is no access to public toilet. Therefore, this research describes stakeholder to understand the existing condition and make an improvement in the future.
\end{abstract}

\section{Article Info}

- Received : June 30, 2019

- Revised : August 12, 2019

- Published : September 15, 2019

- No. Pages : 289-296

- DOI : 10.33019/ijbe.v3i3.214

- JEL : L83

- Keywords : exploration, tourists' perception, principal component analysis

\section{Introduction}

Tourism sector could be a source of income and job opportunity for many people in the economy (Chia-Lin Chang, Thanchanok Khamkaew, \& Michael Mcaleer, 2012). Proper tourism development can involve all levels of society; it means this sector could be a broad ecosystem in carrying out sustainable economic development. (Basiago, 1999; Yunis, 2009). The inclusiveness of economic in the tourism sector in Pangkalpinang, Indonesia rapidly sustain in the last 5 years. Several tourist destinations have developed with a large market share and have been dominated by domestic tourists. Unlike tourism development on a high commercial company, there is high growth of tourism development in low commercial block. Therefore, the information about market structure in domestic tourism sector is interesting to be explored.

Kumar (2016) stated that domestic tourists are people who make trip and come from the area itself. Based on the purpose of doing the trip, domestic tourists have three types, they are common interest tourist, holiday tourist and business tourist. This research does the approach on the two types of tourists; first is common interest tourist that doing trips for meeting the colleague, friend and family that does not emphasize on the facilities and the beauty of destinations but emphasize on public places, reachable places and appropriate budget. The other one is holiday tourist who uses more of his free time to look around, to get recreation, and playing with family. The purpose of this research is to explore the development of tourism 
market potential and market perception that is conducted to domestic tourists. The process of developing and expanding market share will be increased when the demand also increases. The strategy in developing tourist destination can be conducted by adding services and new products so that we can know consumers' interest. We also should conduct product innovation that can be a strategy in attracting the tourists both in terms of quantity and quality of the product. The tourism destinations that have the potential value to be developed for domestic tourists are Bangka Botanical Garden (BBG), Taman Mandara dan Taman Merdeka in Pangkalpinang. Those third tourist destinations become an attraction for surrounding community in conducting tourism activities by three types of domestic tourists.

Bangka Botanical Garden (BBG) is one of favourite agricultural tourism in Bangka Belitung that has green area as wide as 300 hectares and the location is also strategic. The attraction of this place is the cool atmosphere and the tourists can get knowledge about agriculture, animal boundary and fisheries which have run well currently. Taman Mandara is almost the same as Taman Merdeka which is appropriate to young people as reachable places with provided budget. Those third destinations are recommended as the domestic tourism places because they are reachable, on budget, and comfortable as a place of recreation and gathering with family. Kumar (2016) and Suhel \& Bashir (2018) just explained about the contribution of tourism sector to economic growth, It doesn't give quite a specific solution at all. Main problem to developed tourism sector is how we approach the market of tourism industry, especially about consumer behaviour. The contribution of tourism sector in Indonesia is not too significant if we reviewed from the macro side. This research tries to conduct exploration in the development of domestic tourism from the micro side through developing the industry. Therefore, the information about inclusive economics and analysis of market share is expected to be a good tool for academics, companies and governments in a developing ecosystem in long term.

The development of investment in the tourism sector in Bangka Belitung is more focused on large-scale investments such as 4-star hotels and others. it is very contradictory if we see The data from BPS (Indonesian Central Bureau of Statistics) shows that the average time of people to stay overnight in Bangka Belitung hotel is only 1-2 days. It is also known that the contribution of tourism sector in Bangka Belitung is only 2.3 percent so that the analysis of macro development in tourism is not able to explain the development of this sector accurately. Therefore the analysis of domestic tourism with domestic tourists will provide more accurate information, especially in terms of economic development.

\section{Literature Reviews}

\section{Domestic Tourists}

Domestic tourists are tourists who come from within the country. Domestic tourists do travelling for domestic travel to let go of curiosity about a pleasant place. They do not need passport and visa when doing a trip. It is known that countries with a large dimension area like India, America and Indonesia have a large ratio of domestic tourists that doing domestic travelling compared with a small country. From a geographical point of view, domestic tourists are come from local travelling, regional travelling and even travelling between provinces (Kumar, 2016). There are some characteristics of domestic tourist in Indonesia, they are:

1. Common purpose tourism

Common purpose tourism usually did the travel by visiting family or friend who is in a certain region. this type of tourism doesn't demand good vacation facilities because they are doing vacation casually.

2. Holiday tourism 
Tourism activity is conducted when holiday or spare time in which this activity is done when the weather, the time and individual economics support. Sunny weather, tours, recreation and traveling around different cultural sites are looked for by the tourists in this category.

3. Business tourist

The tourists do a business trips to increase his business by attending trade show, conference and certainly professional. They are collaborating business with recreations activities.

For the simplification purpose, this research decides that Prospective respondents in this study were local people from within the island of Bangka with access to visiting tourist destinations by land route. This step is done to get the assumption that domestic tourists can access the destination area with low cost and do not take a lot of time so that tourism activities can be done at any leisure, for example, every week or every month.

\section{Characteristics of Domestic Tourist}

There are two characteristics of tourist:

1. Trip Descriptor

The tourist of trip descriptor is divided into several groups based on the type of the trip. The type of the trip can be divided into the trip for recreation, trip for visiting family or friend, trip for business, trip for health and religion. The trip can be divided base on the distance, such as the type of accommodations, transportation equipment used for travel, organizing trips and the number of expenses that will be incurred on trips or tours.

\section{Tourist Descriptor}

This character is focused on the tourists; it is usually explained with $5 \mathrm{~W}+1 \mathrm{H}$ questions so it can describe the use of different characters such as geographical, socialdemographic and psychographic. (Bohlin et al., 2006)

\section{Previous Research}

The previous research discussed that domestic tourism sector became an income generator in India. Kumar (2016) explained that domestic tourist became the most potential market share for domestic tourism industry it is due to some factors; they are: domestic tourist does not need passport and travel visa, has knowledge about the tourist destination and they are also having insight about traditions and customs of destination that will make them easy to do a vacation. Suhel \& Bashir (2018) analyzed the relationship between tourism sector and economic growth. The analysis had a lot of things to be solved, especially in the field of broad scope segmentation. The analysis of contribution in tourism sector will be seen if connected to the development of business lines related to that sector such as hospitality, transportation, supporting MSMEs and others.

\section{Research Methods}

This research uses two main methods to disclose information that would be reviewed. First, the researcher will explore market share using simple tabulation analysis. In conducting calculation to the market share, this research will estimate by calculating the average expenditure of visitors. Second, this research would use Principle Component Analysis in compiling perception index of domestic tourist in some aspects.

There are four aspects of perception we would explore, the first aspect is perception on economic aspects of domestic tourist destination in Pangkalpinang such as the price and 
accessibility, the second aspect is regarding the convenience in doing recreation at the destinations, the third aspect is public facilities at the tourist destinations, and the fourth aspect is regarding the availability of merchandise in the domestic tourist area. Those forth aspect would be defined on continuous data of individual tourist perception. To simplified the continuous data of perception, this research would treat continuous data as a three-category of equal interval. For better information follow this table:

\begin{tabular}{cc}
\hline Interval & Category \\
\hline $0-33$ & Bad \\
\hline $34-66$ & Moderate \\
\hline $67-100$ & Good \\
\hline
\end{tabular}

Where the value of continuous data in the part of 33 percent in bottom interval shows that the perception of tourists to these aspects is bad and 33 percent of the highest interval category shows a good perception.

\section{Principle Component Analysis Method}

Principal Component Analysis is a technic which is conducted to extract several orthogonal linear combinations from a set of variables. Orthogonal linear combinations on a set of variables provide information on characteristics of the set of variables (Filmer \& Pritchett, 2001). PCA is a technic to build new variables which is linear combination from original variables. The maximum quantity of the new variables will be the same as the old variable, and those new variables do not correlate with each other. Intuitively, the analysis of main components is a linear index which capturing information of a set of variables with the highest eigenvalue. The following is the formulation of variable which is formed to be a linear combination from a set of variables for each tourist as the respondent.

Note:

$$
\begin{gathered}
a_{1 j}=v_{11} A_{1 j}+v_{12} A_{2 j}+\cdots+v_{1 N} A_{N j} \\
j=1, \ldots . J \\
a_{N j}=v_{N 1} A_{N j}+v_{N 2} A_{2 j}+\cdots+v_{N N} A_{N j}
\end{gathered}
$$

$\mathrm{J}=$ tourist/respondent

1...N = Tourism Support Aspects (security, price, facilities, accessibility)

$\mathrm{A}_{1 \mathrm{j}} \ldots \mathrm{A}_{\mathrm{Nj}} \quad=$ respondent perception index $1 \ldots \mathrm{j}$

$\mathrm{v}_{11 \ldots} \mathrm{v}_{\mathrm{NN}} \quad=$ coefficient from each variable of each respondent

$\mathrm{a}_{\mathrm{ij}} \ldots \mathrm{a}_{\mathrm{Nj}} \quad=$ answer score $\mathrm{i}$ of respondent $\mathrm{j}$

Model 2, A is component while $\mathrm{v}$ is the coefficient of each component in each variable ( $\mathrm{v}$ is the same for each respondent). The solution is indeterminate because the variable that can be observed is only on the left side of the model $\left(\mathrm{a}_{1 \mathrm{j}}\right)$. Principal Component Analysis can solve the indeterminate problem by finding linear combination from the set of variables with maximum variance. First principal component $\left(A_{1 j}\right)$ is linear combination with the variant maximum score is followed by the second linear combination $\left(A_{2 j}\right)$, where $\left(A_{2 j}\right)$ is orthogonal from the first linear combination with high variants. Look at the model (2):

$$
\begin{gathered}
A_{1 j}=f_{11} a_{1 j}+f_{12} a_{2 j}+\ldots+f_{1 N} a_{N j} \\
\quad j=1, \ldots J \\
A_{N j}=f_{N j} a_{1 j}+f_{N 2} a_{2 j}+\cdots+f_{N N} a_{N j}
\end{gathered}
$$


The scoring factor of the model is obtained from inverse that is conducted in model 2. The score of the first principal component is on the first line at model 1. The last step in creating perception index is by normalizing the data of a with the average value and its deviation standard. Perception index which is formed from is as follows:

Note:

$$
A_{1 j}=\frac{f_{11}\left(a_{1 j}^{*}-a_{1}^{*}\right)}{s_{1}^{*}}+\cdots+\frac{f_{1 N}\left(a_{N j}^{*}-a_{N}^{*}\right)}{s_{N}^{*}}
$$

$\mathrm{a}_{1 \mathrm{j}}^{*}=$ answer score of component 1 on respondent $\mathrm{j}$

$\mathrm{a}_{1}^{*}=$ average score of perception on aspect 1 (e.g. the price) at all respondents (1.J)

$s_{1}^{*}=$ score of deviation standard from the perception of aspect 1 (e.g. the perception on accessibility of destination)

\section{Results}

\section{Principle Component Analysis}

Arranging the index of perception of society on 3 tourist destinations in Pangkalpinang, this research uses some measurement indicators such as accessibility, public facilities (toilet, parking lots, and places of worship), the cleanliness, prices, services and security. The purpose of PCA method is conducted to give the appropriate weight for each component of the question regarding perception. The appropriate weight with all characteristic of setting data resulting index score that is expected to be able to represent tourist perception well. Look at the following table:

Table 1: Principle components/ Correlation

\begin{tabular}{lrrr}
\hline Component & Eigenvalue & Proportion & \multicolumn{2}{c}{ Cumulative } \\
\hline Comp1 & 2.22186 & 0.2777 & 0.2777 \\
Comp2 & 1.394 & 0.1742 & 0.452 \\
Comp3 & 1.07347 & 0.1342 & 0.5862 \\
Comp4 & 0.93663 & 0.1171 & 0.7032 \\
Comp5 & 0.891792 & 0.1115 & 0.8147 \\
Comp6 & 0.662556 & 0.0828 & 0.8975 \\
Comp7 & 0.486485 & 0.0608 & 0.9583 \\
Comp8 & 0.333214 & 0.0417 & 1 \\
\hline Description: Obs as many as 8 & &
\end{tabular}

Source: the processed data, 2019

This study uses component 1 in predicting continuous perception values. Results show that the value of component 1 can represent the perception of tourists with the highest eigenvalue level. component 1 was able to explain the overall data characteristics of 27.7 percent. To calculate the principal component value using component 1, Table 2 describes $f$ value that applicate on the (3) formulation.

Table 2: Principle components (eigenvectors)

\begin{tabular}{cc}
\hline Variable & Comp 1 \\
\hline var 1 & 0.4001 \\
$\operatorname{var} 3$ & 0.0746 \\
$\operatorname{var} 4$ & 0.4358
\end{tabular}




\begin{tabular}{cc}
\hline Variable & Comp 1 \\
\hline var 5 & -0.0982 \\
$\operatorname{var} 6$ & 0.313 \\
$\operatorname{var} 7$ & 0.3665 \\
$\operatorname{var} 8$ & 0.4211 \\
$\operatorname{var} 9$ & 0.4755 \\
\hline
\end{tabular}

Source: the processed data, 2019

This result indicates that index score will use the score weight from comp 1 with the highest score of eigenvalue is 2.221. Comp1 can explain all of the characteristics data with the score is 27 percent. Therefore, the score of comp1 is used as the reference of weight of each question where there are 9 questions and 6 criteria that have been set. But one question could not be a component in calculating PCA because there is no answer variation from all respondents. The question is about the ease in accessing those tourist destinations. The analysis result using PCA indicates the index score on the respondents that have been filled the questionnaires. This research arranges the scheme of 3 categories of perception with the preparation of categories that are adjusted to the lowest to highest possible values of 3 equal intervals. Three categories of perception consist of 1 for bad, 2 for moderate, 3 for good. Based on the processing data of PCA than the result of its categories as follow:

\begin{tabular}{lccc}
\hline Perception & Bad & Moderate & Good \\
\hline The total of respondents & 3 & 5 & 52 \\
\hline Percentage cumulative & $5 \%$ & $8 \%$ & $87 \%$ \\
\hline So
\end{tabular}

Source: the processed data, 2019.

The result indicates that the majority of domestic tourists have good perceptions of 3 tourist destinations in Pangkalpinang. The data shows that there are 52 respondents have good perception, 5 respondents have moderate perception and 3 respondents have bad perception. The result of tabulation shows that all respondents agree that domestic tourist destination is easy places to be visited. Then, it is founded that in terms of beauty it is also good to note that 57 people agree that domestic tourism destinations in Pangkalpinang are beautiful. The next aspect is affordable food prices that make domestic tourism success in attracting local tourists to travelling. But, the problem of toilet is an aspect that is considered weak and needs improvement because the tourist perception is still not good. From 60 respondents, there are more than 50 percent have a bad perception of the availability of toilet at those tourist destinations.

Some challenges must be faced in conducting surveys on local tourists, especially those from rural areas. It is very difficult to explore perceptions because the average low level of iteration makes the awareness of rural communities to take the time to fill the questionnaire is relatively low. Researchers conducted a deepening of the 3 tourist destinations. The BBG (Bangka Botanical Garden) and Alun Alun City destinations in Pangkalpinang are child-friendly tourist destinations. the Mandara park tourist destination has a characteristic to hang out spot for young people. The main orientation of local tourists who are families is the availability of children's play facilities but at an affordable price. Meanwhile, the orientation of tourist destinations by people under 35 years is the availability of fast food and the density of visits from the same circle to simply find new friends who have the same vision.

This study also provides an overview of the concept of tourist destinations for local tourists. Two concepts have been explored. The first is the concept of travel with child-friendly based. The second is a tourism concept that is youth-friendly. Both of these concepts have different 
development patterns, especially in the development of MSME business lines. Examples are MSMEs that are suitable for child-friendly tourist destinations, which are carousel service providers, paid play arenas, car rental cars, painting arenas and traditional snacks for their parents. While MSMEs that are suitable for friendly young tourist destinations are MSMEs that provide fast food such as grilled sausages, grilled meatballs, various types of coffee and others.

\section{Market Share Analysis}

In able to deepen the tourism potential of Pangkalpinang, this study also approaches the value of the sample of respondents as a whole. According to (Mankiw, 2008) Market demand refers to the sum of all individual demands for a particular good or service. The average expenditure for the 60 respondents surveyed is in the range of IDR 25,000 to IDR 50,000 per person. Exploration of market share is important to understand the potential of the velocity of money that exists in this industry and ultimately understand in-depth how its contribution to the economy at large and then we will get specific information about how much increase in people's welfare arising from economic activities in the management of the tourism industry.

This research also conducts the exploration of market share in the local tourism industry in Pangkalpinang. From 60 respondents that have been surveyed, the data shows the result as follows:

\begin{tabular}{cccc}
\hline Expenditure & $<25,000$ & 25,000 to 50,000 & $>50,000$ \\
\hline The total of respondents & 22 & 17 & 21 \\
\hline Percentage cumulative & $37 \%$ & $28 \%$ & $35 \%$ \\
\hline Source: the processed data, 2019. &
\end{tabular}

The result indicates that there is 37 percent of the tourists spend no more than IDR 25,000 for a single visit. There is 28 percent of respondents spend IDR 25,000 to IDR 50,000 for a single visit, and there's 35 percent of respondents spend more than IDR 50,000 for a single visit. It shows that travelling in Pangkalpinang is not expensive and it has a potential to develop MSMEs which selling food at those tourist destinations because the aspect of tourist perception explains that local tourist destinations are attractive due to the low-price range.

In analyzing market potential, this research deepens the consumers budget. The results show that quite several consumers can spend as much as IDR 25,000 or more. For this reason, it will be a good benchmark for investors at UMKM to be more aggressive in investing and increasing their business turnover so that foreign tourists can have additional comfort in travelling. a lot of characteristics arise in digging up information about local tourist behaviour. in terms of budget travel, expectations for scenery and information about tourist attractions government must develop optimism in promoting economic growth through the local tourism sector through accommodation that is prioritized for the development of MSMEs.

\section{Conclusion and Suggestion}

This research aims to explore the information about local tourist perception of domestic tourist destinations in Pangkalpinang. After collecting micro survey data on the individual level, it is founded that 87 percent of respondents have a good perception of several aspects of tourism destinations in Pangkalpinang. 8 percent of respondents have moderate perception and 5 percent respondents have bad perception. In general, the observation of local tourists shows that the implementation of tourism activities in Pangkalpinang has been going well. Development of Pangkalpinang tourism has considerable potential for new sources of growth and the destruction of macroeconomic indicators such as income equity, private investment, 
and even welfare. For this reason, these results can be a major supporter of the very promising market potential to be developed by the private sector and fully supported by the government.

The next result indicates that all of the tourists agree that local tourist destinations in Pangkalpinang are easy to be visited. Culinary costs are affordable and view is beautiful. But the availability of toilet becomes a deficiency in all three tourist destinations. There is more than 50 percent of respondents said that the availability of toilet is lack even more respondents do not have clear information about the availability of toilets at these destinations This research concludes that the management of local tourist destinations has been successful especially in attracting local consumers. For some reasons, there is rapid development of the MSMEs in all of these destinations. The result indicates that on average the tourists spend IDR 25,000 to 50,000 for a single visit. Therefore, the development of an inclusive economy will be successful by developing local tourist destination for some reasons that have been explained.

\section{References}

1) Basiago, A. D. (1999). Economic, social, and environmental sustainability in development theory and urban planning practice. In The Environmentalist (Vol. 19). Kluwer Academic Publishers.

2) Bohlin, M., Seaton, A. V., Jenkins, C. L., Wood, R. C., Dieke, P. U. C., Bennet, M. M., Smith, R. (2006). Tourism. The State of the Art. Geografiska Annaler. Series B, Human Geography. https://doi.org/10.2307/490878

3) Chang, C. L., Khamkaew, T. and Mcaleer, M. (2012). IV estimation of a panel threshold model of tourism specialization and economic development. Tourism Economics, 18(1), 5-41.

4) Filmer, D., \& Pritchett, L. H. (2001). Estimating Wealth Effects without Expenditure Data-or Tears: An Application to Educational Enrollments in States of India. Demography. https://doi.org/10.2307/3088292

5) Kumar, N. R. (2016). Significance of Domestic Tourism in India as a Major Revenue Generator. Asia Pacific Journal of Research, 1(Xxxviii), 6-9. Retrieved from https://apjor.com/downloads/140420162.pdf

6) Management, H., Bhagawat, P., Mahajana, M., \& Road, K. R. S. (2016). Significance of Domestic Tourism in India as a Major Revenue Generator. (Xxxviii), 6-9.

7) Mankiw, G. (2008). Principles of Microeconomics (5e ed.). Cengage Learning products.

8) Suhel, S., \& Bashir, A. (2018). The role of tourism toward economic growth in the local economy. Economic Journal of Emerging Markets, 10(1), 32-39. https://doi.org/10.20885/ejem.vol10.iss1.art4

9) Yunis, E. (2009). Tourism and employment: An overview by UNWTO. In Fifth UNWTO International Conference on Tourism Statistics (pp. 1-13). 